\title{
Human resources as a factor in ensuring the security of the Russian Federation economic development
}

\author{
Maria F. Mizintseva \\ Doctor of Economics, Head of the Department of \\ Economics and management, VINITI RAN \\ Professor of the Management Department, Economics \\ Faculty, Peoples' Friendship University of Russia (RUDN \\ University) \\ Moscow, Russian Federation \\ mizintseva_mf@pfur.ru,mfmizin@mail.ru
}

\begin{abstract}
Anna R. Sardarian
Candidate of Economics, associate professor of the Management Department, Economics Faculty, Peoples' Friendship University of Russia (RUDN University) Senior researcher of the Department of Economics and management, VINITI RAN
\end{abstract}

Moscow, Russian Federation

sardaryan_ar@rudn.university, anna_al_edu@mail.ru

\begin{abstract}
The article examines human resources in the Russian Federation and identifies main aspects of personnel security. It also reveals the nature and structure of personnel security, describes the role of the human resources evaluation system in the process of ensuring this type of security, presents briefly the structure and specificities of the Russian human resources taking into consideration such indicators as: population size, dynamics of population changes, economically active population, unemployment rate, GDP per capita, the number of people whose income is below the poverty line, the ethnic composition, and a set of the following modern integrated indices: Human Development Index, The Global Competitiveness Index, Education Index, Quality-of-life index, The Gender Equity Index. In accordance with the findings obtained, the main threats for the safe development of the economy of the regions in the country are the following: depletion of human resources; neetyouth, provoking many social ills; erosion of traditional system of qualified personnel training; the prevalence of private interest over national ones; the collapse of spiritual and moral values especially among the younger generation; and poverty of the population. The article highlights the significance of searching for effective methods of eliminating unfavorable threats to human resources development at the governmental, regional and municipal levels.
\end{abstract}

Keywords- human resources, economic security, economy of regions, Russian Federation, personnel security, labor force, human capital

\section{INTRODUCTION}

The country's potential is determined by various types of resources: manufacturing, financial, cultural, human, the harmonious utilization of which is the most important function of the government. In the current situation of transforming Russian society, facing a number of serious problems in the social and economic sphere and increased competition for geopolitical supremacy in the world, human resources have become an important factor in ensuring the security of both the country in general and some regions in particular. Governments are more and more focusing their attention on social issues, expanding systemic study of the structure and characteristics of human resources as a unique resource with enormous potential, which is capable to significantly change the country's position in the world, as well as provide security in such areas as technology, engineering and economy. The recognition of this fact leads to understanding that competitiveness of a country, as well as its safe economic development depends not so much on the material assets as much as the qualification and potential of the country's human capital.[1]

A comprehensive and sound analysis of the sources and factors of economic and social development, as well as the growth of material wealth and well-being carried out in the second half of the 20th century resulted in a fundamentally new understanding of the place and role of a person in the economy. It was a new understanding of the centrality of a human person in the economy that objectively promoted the revival and formation of a modern concept of socio-economic development. In the XXI century it is recognized that a person is the main goal and main actor - the beneficiary of the economic development and social progress; while the economic growth of any country is considered dependent on the level of human resources development. [2] A number of authoritative studies have been devoted to this issue, including the research by Romer P. [3], Lucas R. [4], Aghion Ph. [5], Grossman J., [6] Drucker P. [7], Kenan T. [ 8], Redman T., [9] Fatkhutdinov R.A. [10]. Studies of the role of human resources in ensuring Russia's can be found in the works by the following authors: Abalkin L. [11], Yakovlev E.N., Chebotarev S.S., Zvyagin A.A. [12]. As for the Englishlanguage literature, certain aspects of the human resources development in the Russian Federation are touched upon in 
the works by: Horie N.,1[13] Filippov S.,[14] Puffer S.M., McCarthy D.J.,[15] Hayashi H.[16], Becker Ch., Mendelsohn S.J., Benderskaya K.[17]

At the same time we have to state the fact that in spite of rising topicality of this issue, there are still not enough such studies. In this regard, it is important to emphasize once again the importance of studying this issue, to identify the main threats to the safe development of the country's economy in the field of human resources, to list the key threats in this sphere in the Russian Federation and to describe their main features.

The objective of the article is to examine key features of country's human resources at the present stage of social and economic development and highlight key challenges in this sphere for the Russian Federation. In accordance with the objective, the following important tasks were set: to reveal the nature and structure of human resources security, to determine the role of the human resources evaluation in the process of ensuring personnel security, on the basis of statistical data to characterize the key features of the human resources in the Russian Federation, and to identify the most important threats to ensuring the human resource security of the country's economic development.

\section{MAterials AND Methods (MODEL)}

This publication uses the methods of analysis, generalization, factorial analysis, and grouping. The object under study is human resources in the Russian Federation. Findings and conclusions of the article are based on works by scholars of Western Europe, North America and Russia, materials of statistical authorities of the Russian Federation, as well as information taken from specialized sites.

\section{RESULTS AND DISCUSSION}

A. The nature and structure of personnel security. The main components of any country's security are: military, information, political, financial, technological, economic, public, and environmental. In the situation of unstable development of national and regional economies, the growth of uncivilized forms of competition, reduced ethical values of all participants in social and economic relations, social risks are increasing, including risks to country's labor resources. They are now increasingly playing one of the key roles in ensuring the security of economy and sustainable development of the country.

Among the specific security threats in the field of human resources (so-called personnel security of the country) we can name the following: threats to intellectual security, threats to the security of labor resources (prevalence of private interests, reduction of motivation for work, etc.), risk to destroy the spiritual and moral potential of the country. [18] All this leads to the emergence of such socially unfavorable trends as: migration, including highly qualified personnel; increase in crime, drug addiction, alcoholism, and domestic violence; the growth of neet-youth generation (young people neither in the labour force nor in education or training), etc. Thus, threats to personnel security hinder economic development of the country, trigger capital outflows, tax evasion, expansion in the shadow economy, etc.

In general, personnel security can be understood as the process of reducing the risks and threats associated with the country's labor resources (their professional, intellectual and spiritual potential) and social and labor relations on the part of the personnel policy at various levels (national, regional, municipal). The most important goal of personnel security can be called the creation of a personnel potential of the country as a key intellectual and professional resource of the society ensuring its integrity and high rates of social and economic development, and sustainable competitiveness in the international division of labor. [19]

B. The role of assessment in ensuring human resource security. The analysis of human resources in the region plays a particular part in ensuring the personnel security, which is based on a number of indicators (population size, age and gender, ethnic structure, birth rate, level of education, poverty rate, etc.). Thus, the assessment of the country's human resources is carried out using the following tools: population censuses, population registers, demographic research of certain population groups, and sociological surveys. A particular importance in the procedure for assessing human resources has modern integrated indicators, including: Human Development Index, The Global Competitiveness Index, Education Index, Quality-of-life index, The Gender Equity Index, etc. When calculating these indices dozens of different indicators are taken into account. For example, The Global Competitiveness Index, developed in 2994 by Xavier Sala i Martín, is based on the indicators of: national infrastructure, microeconomic stability, health, primary education, labor market efficiency, technological level, higher education, professional training, innovation potential, competitiveness of companies, etc.

The Gender Equity Index, proposed by the United Nations in 1995, takes into account such indicators as: the ratio of the male and female employment in the country, the wages of women and men both in the sectors of the economy and in positions held, the ratio of the sexes in the government apparatus and among senior managers of large national companies, the level of literacy of men and women and their ratio, the balance of women/men in educational enrollment rate, etc., Consequently, the procedure of human resources assessment based on different criteria, especially on integrated indicators is considered to be one of the most important instruments in the field of ensuring personnel security.

C. Human resources of the Russian Federation and key personnel threats to ensuring economic security. According to the All-Russian Census of Population held in 2010, the population of the Russian Federation was 142.9 million people. In 2017, it was 146.8 million people. (fig. 1). Russia is among the ten most populated countries in the world, along with China, India, the United States, Indonesia, Brazil, Pakistan, Bangladesh, Nigeria and Japan. [20] The population 
in the country is expected to grow by 2020 to 147.5 million people. [21]

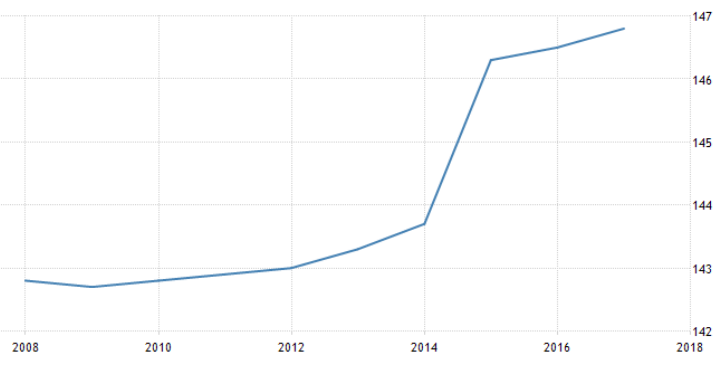

Fig. 1. The population increase from 2008 to 2017

Source: Site Tradingeconomics [Electronic resource] Access mode: https://ru.tradingeconomics.com/russia/population

According to the Federal State Statistics Service, the population of working age totaled 91161.1 thousand people in the country in 2016 , including 81354.2 thousand people of working age, and 2834.4 thousand foreign migrant workers. Moreover, as compared to 2010, the number of people of working age in the Russian Federation significantly decreased, which emphasizes another urgent problem of human resources in Russia - the reduction in the number of national labor resources (Table 1.).

Table 1. Average annual number and structure of labor resources in the Russian Federation (thousands of people)

\begin{tabular}{|c|c|c|c|c|c|}
\hline & 2010 & 2013 & 2014 & 2015 & 2016 \\
\hline TOTAL: & \multirow{2}{*}{\multicolumn{5}{|c|}{\begin{tabular}{|l|l|l|l|l|l|}
93114.6 & 92388.6 & 92021.4 & 92706.1 & 91161.1 \\
\end{tabular}}} \\
\hline Including: & & & & & \\
\hline $\begin{array}{l}\text { able-bodied population } \\
\text { of working age }\end{array}$ & \multicolumn{2}{|c|}{\begin{tabular}{|l|l|l|l|}
85450.5 & 83135.7 \\
\end{tabular}} & 82220.7 & 82461.3 & 81354.2 \\
\hline foreign migrant workers & 1976.4 & 2978.1 & 3322.3 & 3387.5 & 2834.4 \\
\hline $\begin{array}{l}\text { People over active } \\
\text { working age and } \\
\text { teenagers, employed } \\
\text { in the economy }\end{array}$ & 5687.7 & 6274.8 & 6478.4 & 6857.3 & 6972. \\
\hline \multicolumn{6}{|l|}{ Including: } \\
\hline $\begin{array}{l}\text { People over active } \\
\text { working age }\end{array}$ & 5610.8 & 6202.7 & 6408.2 & 6790.5 & 6905.9 \\
\hline Teenagers over $14-15$ & 76.9 & 72.1 & 70.2 & 66.8 & 66.6 \\
\hline
\end{tabular}

Source: compiled by the authors on the basis of materials of the Federal State Statistics Service of the Russian Federation - [Electronic resource] - Access mode: http://www.gks.ru

In all constituent territories of the Russian Federation we can see albeit a slight growth in employment. This is especially noticeable in the Central Federal District of the country (tab. 2.)
TABLE II. The number of employed by the federal territories of the Russian Federation at an average annual rate. (thousands of people)

\begin{tabular}{|c|c|c|c|c|c|c|c|}
\hline $\begin{array}{l}\text { Federal } \\
\text { territories }\end{array}$ & 2010 & 2011 & 2012 & 2013 & 2014 & 2015 & 2016 \\
\hline The Central & 1971 & 2005 & 2038 & 2030 & 2047 & 2036 & 2052 \\
\hline Federal District & 6.3 & 6.9 & 2.6 & 9.6 & 1.1 & 3.3 & 6.6 \\
\hline $\begin{array}{c}\text { The } \\
\text { Northwest }\end{array}$ & 7188 & 7280 & 7346 & 7253 & 7225 & 7244 & 7256 \\
\hline Federal & .0 & .3 & .9 & .9 & .0 & .2 & .7 \\
\hline & 6438 & 6486 & 6559 & 6537 & 6517 & 7634 & 7645 \\
\hline Federal Di & .7 & .8 & .6 & .8 & .4 & .1 & .7 \\
\hline $\begin{array}{l}\text { The North } \\
\text { Caucasian }\end{array}$ & 3638 & 3791 & 3898 & 3938 & 4036 & 3993 & 4035 \\
\hline Federal Dis & .6 & .4 & .6 & .5 & .8 & .5 & .4 \\
\hline & & & & & & & \\
\hline & 1466 & 1480 & 1488 & 1483 & 1481 & 1475 & 1471 \\
\hline Federal Dis & 4.5 & 0.8 & 3.2 & 8.2 & 2.3 & 9.0 & 0.4 \\
\hline & 6005 & 6102 & 6158 & 6171 & 6132 & 6103 & 6054 \\
\hline Fede & .1 & .3 & .7 & .6 & .9 & .0 & .9 \\
\hline & 9140 & 9133 & 9116 & 9131 & 9150 & 9061 & 9003 \\
\hline Federal Dist & .4 & .4 & .8 & .6 & .1 & .5 & .5 \\
\hline The Far Easte & 3142 & 3204 & 3199 & 3210 & 3193 & 3165 & 3159 \\
\hline Federal District & .1 & .7 & .0 & .4 & .4 & .0 & .2 \\
\hline
\end{tabular}

Source: compiled by the authors on the basis of materials of the Federal State Statistics Service of the Russian Federation

- [Electronic resource] - Access mode: http://www.gks.ru

Unemployment rate in the country, although has been varying within $4-5 \%$ in recent years, nevertheless, according to official data of state statistical agencies, today there is a serious problem with the employment of young people unemployed young people in Russia accounted for $23.6 \%$. [22] This causes a serious problem among the younger people in the country - the problem of neet-youth (young people neither in the labour force nor in education or training). For the first time this concept began to be used in the late 1990s, [23] and today it is one of the current issues in studying the problems of youth employment. The index of this category of young people in recent years was in Europe from 5\% to 22\% depending on the countries (Netherlands, Germany, Austria, Denmark (5-7\%), Greece, Italy, Spain, Croatia and Bulgaria $(19-22 \%)$. In Russia, this index has totaled about $12 \%$ in recent years. [24]

Another problem for the country is migration, including highly skilled personnel. And although the migration outflows to foreign countries from the Russian Federation amounted to 253,498 people in 2016 and decreased in comparison with the previous year, nevertheless, the migration gain has fallen compared to 2014 and amounted to 298,410 people (Table 3). 
TABLE III. Migration flows in RF and migration gain in RF in 2010-2016

\begin{tabular}{|c|c|c|c|c|}
\hline Years & Outward flow & $\begin{array}{c}\text { within } \\
\text { RF (other } \\
\text { regions) }\end{array}$ & $\begin{array}{c}\text { To foreign } \\
\text { countries }\end{array}$ & $\begin{array}{c}\text { Migrati } \\
\text { on gain }\end{array}$ \\
\hline 2010 & 1238758 & 1212296 & 26462 & 254089 \\
\hline 2011 & 1920283 & 1890734 & 29549 & 470279 \\
\hline 2012 & 2507994 & 2409371 & 98623 & 461561 \\
\hline 2013 & 2741175 & 2587935 & 153240 & 473010 \\
\hline 2014 & 2915365 & 2659680 & 255685 & 433684 \\
\hline 2015 & 3072591 & 2781069 & 291522 & 292919 \\
\hline 2016 & 3053285 & 2799787 & 253498 & 298410 \\
\hline
\end{tabular}

Source: compiled by the authors on the basis of materials of the Federal State Statistics Service of the Russian Federation

- [Electronic resource] - Access mode: http://www.gks.ru

The Russian Federation is a multinational country, with an ethnically complex population. Thus, more than 180 nationalities live on the territory of the Russian Federation. According to the latest population census in 2010, the country had the seven most numerous nations with more than 1 million people (Russians, Tatars, Ukrainians, Bashkirs, Chuvashes, Chechens and Armenians). [25] In comparison with the Russian census data in 2002, the number of Russians decreased by $4.2 \%(4,872,211$ people). The number of Ukrainians, Tatars, Chuvashes and Bashkirs has also declined; the population of Chechens and Armenians increased by $5.23 \%$ and $4.59 \%$, respectively [25].

The percentage of the country's population with incomes below the poverty line is growing (from $12.5 \%$ in 2010 to $13.4 \%$ in 2016) (Table 4). Moreover, in cities this percentage is $61.8 \%$, and in the countryside $-38.2 \%$ (Table 5.).

TABLE IV. The share of the population of the Russian Federation with incomes below the poverty line established at the international level, taking into account the purchasing power parity (\% of the total population)

\begin{tabular}{|c|c|c|c|c|c|}
\hline & \multicolumn{4}{|c|}{$\begin{array}{l}\text { The share of the population with per } \\
\text { capita income lower than }\end{array}$} & \multirow{2}{*}{$\begin{array}{l}\text { For reference: the } \\
\text { share of the } \\
\text { population with } \\
\text { income below the } \\
\text { poverty line }\end{array}$} \\
\hline & $\begin{array}{l}\$ 1.90 \\
\text { per day }\end{array}$ & $\begin{array}{l}\$ 3.90 \\
\text { per day }\end{array}$ & $\begin{array}{c}\$ 5 \text { per } \\
\text { day }\end{array}$ & $\begin{array}{c}\$ 10 \\
\text { per day }\end{array}$ & \\
\hline 2010 & 0.0 & 0.5 & 1.2 & 8.6 & 12.5 \\
\hline 2011 & 0.0 & 0.5 & 1.1 & 8.3 & 12.7 \\
\hline 2012 & 0.0 & 0.4 & 1.0 & 7.7 & 10.7 \\
\hline 2013 & 0.0 & 0.3 & 0.8 & 6.5 & 10.8 \\
\hline 2014 & 0.0 & 0.3 & 0.8 & 6.7 & 11.2 \\
\hline 2015 & 0.0 & 0.3 & 0.9 & 6.9 & 13.3 \\
\hline 2016 & 0.0 & 0.4 & 1.0 & 7.7 & 13.4 \\
\hline
\end{tabular}

Source: data of the Federal State Statistics Service of the Russian Federation [Electronic resource]. Access mode: http://www.gks.ru
TABLE V. Distribution of the poor people in the Russian Federation according to their place of residence, $\%$

\begin{tabular}{|c|c|c|c|c|c|}
\hline & 2012 & 2013 & 2014 & 2015 & 2016 \\
\hline $\begin{array}{c}\text { Residing in cities - } \\
\text { total }\end{array}$ & 59.6 & 58.7 & 61.1 & 62.4 & 61.8 \\
\hline $\begin{array}{c}\text { Residing in rural } \\
\text { settlements - total }\end{array}$ & 40.4 & 41.3 & 38.9 & 37.6 & 38.2 \\
\hline
\end{tabular}

Source: Compiled by the authors based on the materials of the Federal State Statistics Service of the Russian Federation [Electronic resource]. Access mode: http://www.gks.ru

The analysis of human resources on the basis of integrated indices plays an important role. So, according to the Human Development Index, Russia ranks 50th out of all countries in the ranking, (Education Index) is ranked 34th in the ranking, 52nd The Gender Equity Index (Table 6). Obviously, the country is not even among top 30 countries by these indices.

TABLE VI. Indicators of human resources of the Russian Federation by integrated indices

\begin{tabular}{|c|c|c|}
\hline Index & Value & Rating position \\
\hline Human Development Index & 0.798 & 50 \\
\hline Education Index & 0.816 & 34 \\
\hline The Gender Equity Index & 0.314 & 52 \\
\hline Quality-of-life index & 5.31 & 72 \\
\hline The Global Competitiveness Index & 4.51 & 43 \\
\hline The Happy Planet Index & 34.518 & 122 \\
\hline
\end{tabular}

Source: compiled by the authors on the basis of the following materials: Review of the United Nations "World Population Prospects". The 2015 Revision, PDF format 2015. "United Nations World Population Prospects: The 2015 Revision "(PDF) [Electronic resource] - Access mode: http://esa.un.org/unpd/wpp/Publications/Files/World_Populati on_2015_Wallchart.pdf; Humanitarian Encyclopedia. Center for Humanitarian Technologies. The Gender Equity Index according to UNDP [Electronic resource]. - Access mode: http://gtmarket.ru/ratings

Thus, having analyzed the key indicators of Russia's human resources, we identified the main "problem areas", among which: reduction of labor resources consisting of citizens of the country, reduction in the main nations in the country (Russians, Ukrainians, Tatars, Bashkirs), low living standards, high rate of youth unemployment, etc. In this regard, the threats related to human resources in the country are obvious: depletion of human resources (insufficiency of natural inflows of the population, "brain drain" from the country); neet-youth, provoking serious social ills (drug addiction, crime, parasitism); erosion of the traditional system of training qualified personnel; degradation of some professions; the collapse of spiritual and moral values, especially among the younger generation. Overall, this explains the importance of searching for effective methods of eliminating unfavorable personnel threats at the national, regional and municipal levels. Both the economic security of the Russian Federation and its competitiveness in the global economic space will depend on the effectiveness of the system of managing these threats. 


\section{CONCLUSION}

Both the safe economic development of the country and the well-being of its citizens in the social, cultural, spiritual and other spheres directly depend on the level of human resources development in the country. Today we can talk about the revolution of human resources, in the course of which the place of these resources in the national economy is changing, their role in achieving sustainable development of the country, the requirements for human resources in modern society, as well as methods of managing human resources that have innovative, intellectual, creative capabilities and development potential. The objectives stated in the article (the study of the main features of the country's human resources at the current stage of social and economic development and the identification of key personnel threats for the Russian Federation) were achieved, the tasks were accomplished: the essence and structure of human resources security were revealed, the role of human resources assessment in the process of ensuring personnel security were identified, the characteristics of the key characteristics of the human resources of the Russian Federation were given, the most important threats to human security for development economy of the country were defined.

The authors hope that further research in this area will become more extensive in the very near future. The inferences, findings and conclusions obtained during this work can contribute to further scientific research and practical developments on the problem of eliminating threats personnel security to ensure the safe development of the economy of both the Russian Federation and other countries of the world.

\section{Acknowledgment}

This paper was financially supported by the Ministry of Education and Science of the Russian Federation on the program to improve the competitiveness of Peoples' Friendship University of Russia (RUDN University) among the world's leading research and education centers in the 2016-2020.

\section{References}

[1] SHamuratova N.B., ZHetesova M.T., Bermuhambetova B.B. CHelovecheskij Kapital kak priznak innovacionnogo razvitiya ehkonomiki // Innovacionnaya nauka. 2015. № 7. S. 166.

[2] Doktorovich A.B. Paradigma socioinnovacionnogo razvitiya: chelovecheskij potencial i intellektual'nyj kapital social'no ehkonomicheskih izmenenij.// Prostranstvo i Vremya. 2015. №1-2 . S. 84.

[3] Romer P.M. Endogenous technological change // Journal of Political Economy. - 1990. - Vol. 98(5), p. 71

[4] Lucas R. E. Lectures on Economic Growth. Harvard University Press. 2002. p. 204

[5] Agijon F., Ujl'yamson Dzh. EHkonomicheskij rost, neravenstvo i globalizaciya: teoriya, istoriya i politicheskaya praktika. Per. S angl. YU. Nabatovoj. Izdatel'stvo. Delo, 2015. 287 s.

[6] Grossman S.J., Hart O.S. An Analysis of the principap. Agent problem econometrica. 1983. January . pp. $7-46$
[7] Druker P. Klassicheskie raboty po menedzhmentu / P. Druker. - M.: Al'pina Pablisher, 2015. - $218 \mathrm{~s}$.

[8] Kinan T. Upravlenie chelovecheskimi resursami. - EHdinburg: HeriotVat, 2008. - $114 \mathrm{c}$.

[9] Redman T., Wilkinson A. Contemporary Human Resource Management: text and cases - Pearson Education Limited, 2008. - 555 c. - ISBN $0273716336,9780273716334$.

[10] Fathutdinov R.A. Konkurentosposobnost': ehkonomika, strategiya, upravlenie. M.: Infra-M, 2000. $312 \mathrm{~s}$.

[11] Abalkin L.I. EHkonomicheskaya ehnciklopediya / Pod red. L. I. Abalkina. - M.: EHkonomika, 1999. - 1055 c.

[12] YAkovlev EH.N., CHebotarev S.S., Zvyagin A.A. CHelovecheskie resursy kak faktor obespecheniya ehkonomicheskoj bezopasnosti Rossii $\mathrm{v}$ sovremennyh usloviyah: pravovaya reglamentaciya, ehkonomicheskaya harakteristika // Vestnik Nizhegorodskoj Akademii MVD Rossii. 2010. №1(12). S.243-247

[13] Horie N. A Note on Human Resources Management in Russia: Path Dependency in Job Design. The Journal of Comparative Economic Studies, Vol.9, 2014, pp.135-141.

[14] Filippov, S. Emerging Russian multinational companies: Managerial and corporate challenges. European Journal of International Management, 6, 2012. pp. 323-341.

[15] Puffer, S. M., \& McCarthy, D. J. Two decades of Russian business and management research: An institutional theory perspective. Academy of Management Perspectives, 25(2), 2011. pp.21-36.

[16] Hayashi, H. Changes of Working Life and Work Motivation in Russia. Journal of Northeast Asia Development, Vol. 15. 2013.

[17] Becker Ch., Mendelsohn S.J., Benderskaya K. Russian urbanization in the Soviet and post-Soviet eras. IIED, UNFPA, November 2012. P.134.

[18] YAkovlev EH.N., CHebotarev S.S., Zvyagin A.A. CHelovecheskie resursy kak faktor obespecheniya ehkonomicheskoj bezopasnosti Rossii $\mathrm{v}$ sovremennyh usloviyah: pravovaya reglamentaciya, ehkonomicheskaya harakteristika // Vestnik Nizhegorodskoj Akademii MVD Rossii. 2010. №1(12). S.243-247

[19] Borisov I.A., Ginieva S.B. Kadrovaya bezopasnost' Rossii: klyuchevye problemy i puti resheniya // Materialy VI Mezhdunarodnoj nauchnoprakticheskoj konferencii. 2014. Izd-vo Ural'skogo gosudarstvennogo ehkonomicheskogo universiteta. Ekaterinburg. S.236-239

[20] http://total-rating.ru - «Vse rejtingi». [Electronic resource] access Mode: http://total-rating.ru/1180-chislennost-naseleniya-v-stranah-mira-na2015-god.html

[21] http://vz.ru/ - Gazeta «Vzglyad». Medvedev nazval prognoziruemuyu chislennost' naseleniya Rossii k 2020 godu. [Electronic resource] access Mode: http://vz.ru/news/2016/4/6/803853.html

[22] Federal state statistics service of Russia [Electronic resource] access Mode: http://www.gks.ru

[23] Bridging the gap: New opportunities for 16-18 year olds not in education, employment or training. Report by the Social Exclusion Unit. July 1999. URL: http://dera.ioe.ac.uk/15119/2/bridging-the-gap.pdf (дата обращения: 5 декабря 2014 г.).

[24] Varshvavskaya E.YA. Molodezh', isklyuchennaya iz sfery zanyatosti i obrazovaniya, v stranah ES i Rossii. // Voprosy statistiki.- №4. - 2015. s. $40-47$

[25] Nacional'nyj sostav Rossii [Electronic resource] Access Mode: http://www.statdata.ru/nacionalnyj-sostav-rossii

[26] Tradingeconomics [Electronic resource] access Mode: https://ru.tradingeconomics.com/russia/population

[27] [United Nations World Population Prospects: The 2015 Revision (PDF) [Electronic resource] Access Mode: http://esa.un.org/unpd/wpp/Publications/Files/World_Population_2015_ Wallchart.pdf

[28] Centr gumanitarnyh tekhnologij. Indeks gendernogo ravenstva po versii PROON. - [Electronic resource] Access Mode: http://gtmarket.ru/ratings 